\title{
Solid-State FTIR Spectroscopic Study of Two Binary Mixtures: Cefepime-Metronidazole and Cefoperazone-Sulbactam
}

\author{
Hassan Refat H. Ali, ${ }^{1}$ Ramadan Ali, ${ }^{2}$ Hany A. Batakoushy, ${ }^{2}$ and Sayed M. Derayea ${ }^{3}$ \\ ${ }^{1}$ Department of Pharmaceutical Analytical Chemistry, Faculty of Pharmacy, Assiut University, Assiut 71526, Egypt \\ ${ }^{2}$ Department of Analytical Chemistry, Faculty of Pharmacy, Al-Azhar University, Assiut 71524, Egypt \\ ${ }^{3}$ Department of Analytical Chemistry, Faculty of Pharmacy, Minia University, Minia, Egypt \\ Correspondence should be addressed to Hassan Refat H. Ali; hareha11374@gmail.com
}

Received 27 September 2016; Revised 16 November 2016; Accepted 11 January 2017; Published 5 March 2017

Academic Editor: Feride Severcan

Copyright (c) 2017 Hassan Refat H. Ali et al. This is an open access article distributed under the Creative Commons Attribution License, which permits unrestricted use, distribution, and reproduction in any medium, provided the original work is properly cited.

The structural information of the pharmaceuticals and insights on the modes of molecular interactions are very important aspects in drug development. In this work, two cephalosporins and antimicrobial combinations, cefepime-metronidazole and cefoperazone-sulbactam, were studied in the solid state using FTIR spectroscopy for the first time. Quantitation of the studied drugs and their binary mixtures was performed by integrating the peak areas of the characteristic well-resolved bands: $v$ $(\mathrm{C}=\mathrm{O})$ band at $1773 \mathrm{~cm}^{-1}$ for cefepime and ring torsion band at $826 \mathrm{~cm}^{-1}$ for metronidazole and $v(\mathrm{C}=\mathrm{O})$ band at $1715 \mathrm{~cm}^{-1}$ for cefoperazone and ring torsion band at $1124 \mathrm{~cm}^{-1}$ for sulbactam. The results of this work were compared with the relevant spectrophotometric reported methods. This study provides data that can be used for the preparative process monitoring of the studied drugs in various dosage forms.

\section{Introduction}

Cefepime hydrochloride (CPM) is a fourth-generation, semisynthetic cephalosporin antibiotic for parenteral administration. It is 1 -[[(6R, 7R)-7-[2-(2-amino-4-thiazolyl)glyoxylamido]-2-carboxy-8-oxo-5-thia-1-azabicyclo [4.2.0] oct 2-en-3-yl] methyl]-1-methylpyrrolidinium chloride, 72(Z)-(O-methyloxime), monohydrochloride, and monohydrate (Figure 1). CPM is commonly used in the treatment of moderate-to-severe infections such as pneumonia, intraabdominal infections, and febrile neutropenia. Metronidazole (MTZ) is (=[1-(2-hydroxyethyl)-2-methyl-5-nitro- $1 \mathrm{H}$ imidazole). Metronidazole is the therapeutic agent of choice for amoebiasis and also used in combination with other antimicrobial drugs against yeast infections [1]. Cephalosporin and MTZ combination regimens have been previously studied for this reason [2]. The efficacy of MTZ combined with ceftriaxone [3], cefuroxime [4], and cefepime [5] was well documented. Cefepime and MTZ combination is the optimum choice for mixing into a single bag because both agents may be administered every 12 hours in patients with normal kidney functions and once daily in patients with impaired kidney [5].

Sulbactam sodium (SBT) is 4-thia-1-azabicyclo [3.2.0] heptane 2-carboxylic acid, 3,3-dimethyl-7-oxo-4,4 dioxo sodium salt, and it is official in the British Pharmacopoeia [6]. Cefoperazone (CFZ), (6R, 7R)-7-[[(2R)-[[(4-ethyl-2, 3dioxo-1-piperazinyl) carbonyl] amino] (4 hydroxy phenyl) acetyl] amino]-3-[[(1-methyl-1H-tetrazol-5-yl)thio] methyl]8-oxo-5-thia-1-azabicyclo [4.2.0] oct-2-ene-2-carboxylic acid (Figure 1), has been combined with SBT in a dosage form (Sulperazone ${ }^{\circledR}$ or Peractam $^{\circledR}$ ) for intra-abdominal infections [7].

FTIR spectroscopy is a prime vibrational spectroscopic technique classified within category I of analytical methods according to the United States Pharmacopeia (USP) [8]. It is considered as a primary and simple tool in providing specific information on the identification and characterization of materials at the molecular level. It was successfully applied for the determination of many pharmaceuticals [9-16]. 
<smiles>CO/N=C(\C(=O)N[C@H]1C(=O)N2C(C(=O)[O-])=C(C[N+]3(C)CCCC3)CS[C@H]12)c1csc(N)n1</smiles>

CPM<smiles>CCN1CCN(C(=O)N[C@H](C(=O)N[C@H]2C(=O)N3C(C(=O)O)=C(CSc4nnnn4C)CS[C@H]23)c2ccc(O)cc2)C(=O)C1=O</smiles>

CFZ<smiles>Cc1ncc([N+](=O)[O-])n1CCO</smiles>

MTZ<smiles>CC1(C)C(C(=O)O)N2C(=O)C[C@H]2S1(=O)=O</smiles>

SBT

Figure 1: The chemical structures of CPM, MTZ, CFZ, and SBT.

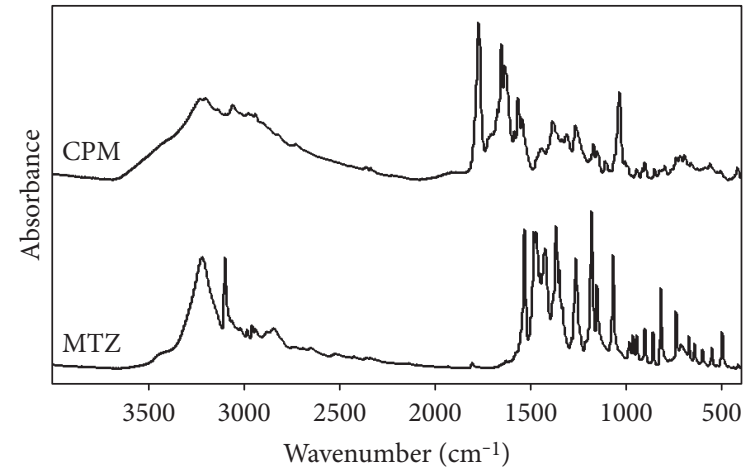

Figure 2: The FTIR spectra of CPM and MTZ in the region of $4000-400 \mathrm{~cm}^{-1}$.

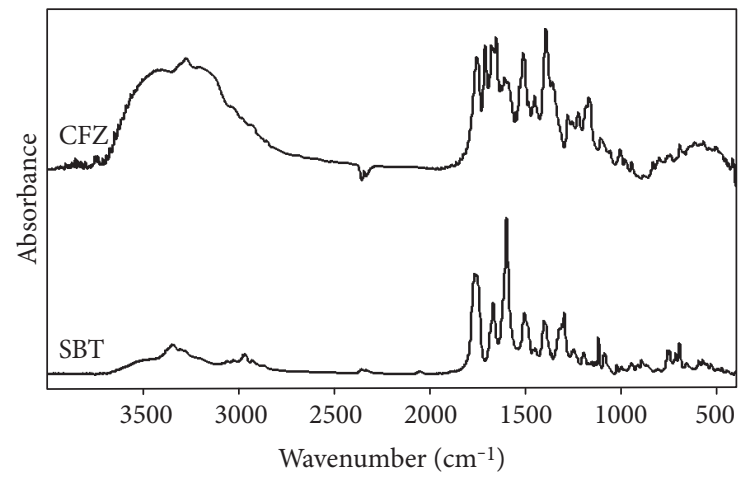

FIgURE 3: The FTIR spectra of CFZ and SBT in the region of $4000-400 \mathrm{~cm}^{-1}$

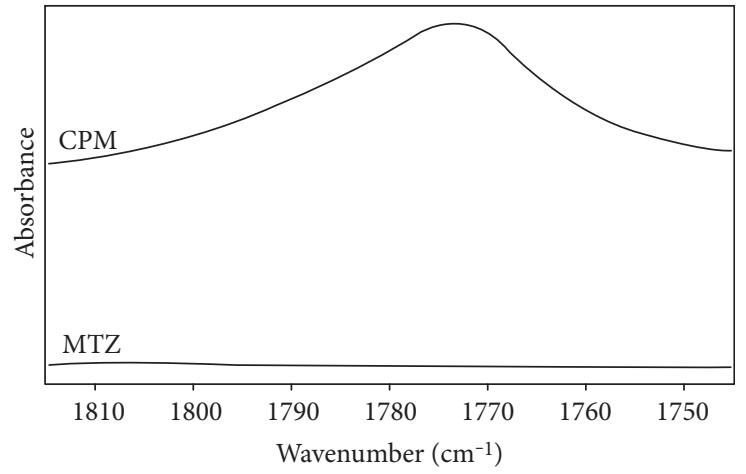

FIgURE 4: The FTIR spectra of CPM and MTZ in the region of $1810-1750 \mathrm{~cm}^{-1}$.

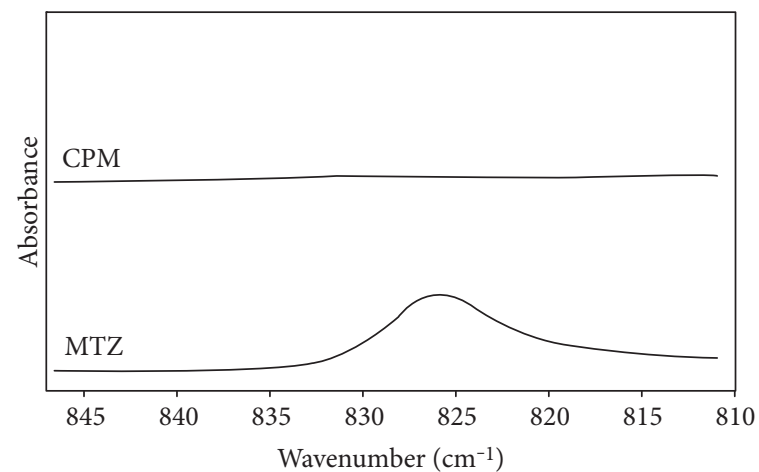

Figure 5: The FTIR spectra of CPM and MTZ in the region of $850-810 \mathrm{~cm}^{-1}$. 


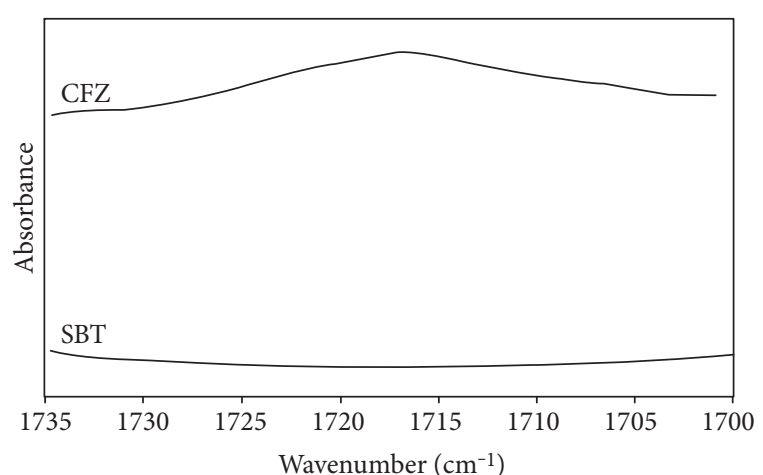

FIGURE 6: The FTIR spectra of CFZ and SBT in the region of $1735-1700 \mathrm{~cm}^{-1}$.

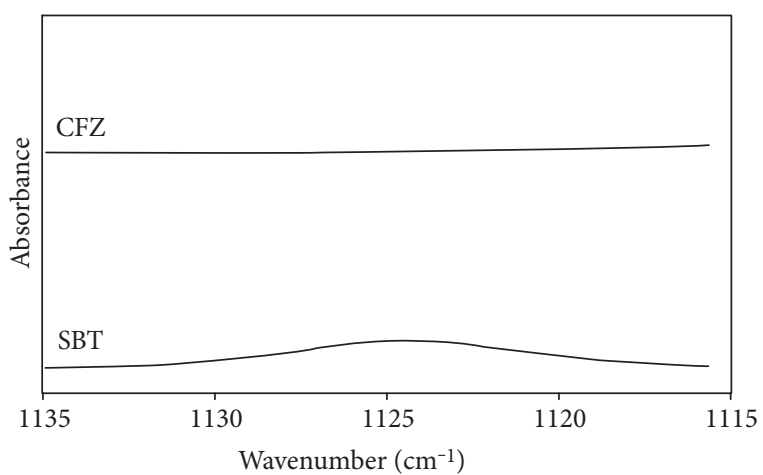

Figure 7: The FTIR spectra of CFZ and SBT in the region of $1135-1115 \mathrm{~cm}^{-1}$.

The aim of the present work is to closely investigate the combinations of CPM-MTZ and CFZ-SBT in the solid state using FTIR spectroscopy as a simple and rapid technique for the first time in comparison with other relevant reported spectrophotometric methods.

\section{Experimental}

2.1. Chemicals. Cefepime hydrochloride was obtained from Bristol-Myers Squibb Co., Cairo, Egypt. Metronidazole was obtained from Egyptian Int. Pharmaceutical Industries Co., E.I.P.I.CO., 10th of Ramadan City, Egypt; cefoperazone was obtained from Pfizer, El-Thawra St., Almaza, Heliopolis, Cairo, Egypt; sulbactam sodium was obtained from AK Scientific Co.; and potassium bromide was purchased from El-Nasr Pharmaceutical Chemical Co., Abo-Zaabal, Egypt. Solvents and other chemicals were of analytical grade and used as received. All chemicals were stored at room temperature in desiccators over phosphorous pentoxide to avoid any deleterious effects from humidity.

2.2. Pharmaceuticals. Pharmaceutical dosage forms containing the studied drugs were purchased from the local market. Maxipime $^{\circledR}$ vials (Bristol-Myers Squibb Co., Cairo, Egypt) were labeled to contain $1000 \mathrm{mg}$ of cefepime per vial. Flagyl ${ }^{\circledR}$ tablets (Sanofi-Aventis, Cairo, Egypt) were labeled
TABLE 1: The distinctive FTIR wavenumbers $\left(\mathrm{cm}^{-1}\right)$ of CPM and MTZ.

\begin{tabular}{lcc}
\hline CPM & MTZ & Proposed assignment \\
\hline $3234 s$ & - & $v\left(\mathrm{NH}_{2}\right)$ \\
- & $3230 \mathrm{sbr}$ & $v(\mathrm{OH})_{\text {alcoholic }}$ \\
$3197 \mathrm{~s}$ & - & $v(\mathrm{NH})$ \\
$3056 \mathrm{~ms}$ & $3097 \mathrm{~s}$ & $v(\mathrm{CH})_{\text {aromatic }}$ \\
$2938 \mathrm{~ms}$ & $2950 \mathrm{~ms}$ & $v(\mathrm{CH})_{\text {aliphatic }}$ \\
$1773 s$ & - & $v(\mathrm{C}=\mathrm{O})_{\text {lactam }}$ \\
$1680 \mathrm{~ms}$ & - & $v(\mathrm{C}=\mathrm{O})_{\text {carboxylic }}$ \\
$1657 m s$ & - & $v(\mathrm{C}=\mathrm{O})_{\text {amide }}$ \\
- & $1535 s$ & $v\left(\mathrm{NO}_{2}\right)$ \\
- & $826 s$ & Ring torsion \\
\hline
\end{tabular}

$m, s$, and $b r$ stand for medium, strong, and broad, respectively. $v$ stands for stretching.

TABLE 2: The distinctive FTIR wavenumbers $\left(\mathrm{cm}^{-1}\right)$ of CFZ and SBT.

\begin{tabular}{lcc}
\hline CFZ & SBT & Proposed assignment \\
\hline $3423 \mathrm{sbr}$ & - & $v(\mathrm{OH})_{\text {phenolic }}$ \\
$3297 \mathrm{~s}$ & - & $v(\mathrm{NH})$ \\
$3090 \mathrm{~ms}$ & $3082 \mathrm{~ms}$ & $v(\mathrm{CH})_{\text {aromatic }}$ \\
$2950 \mathrm{~ms}$ & $2964 \mathrm{~ms}$ & $v(\mathrm{CH})_{\text {aliphatic }}$ \\
$1773 \mathrm{~s}$ & $1767 \mathrm{~s}$ & $v(\mathrm{C}=\mathrm{O})_{\text {lactam }}$ \\
$1717 \mathrm{~s}$ & $1674 \mathrm{~ms}$ & $v(\mathrm{C}=\mathrm{O})_{\text {carboxylic }}$ \\
$1669 \mathrm{~ms}$ & - & $v(\mathrm{C}=\mathrm{O})_{\text {amide }}$ \\
- & $1030 \mathrm{~ms}$ & $v(\mathrm{O}=\mathrm{S}=\mathrm{O})$ \\
- & $1124 \mathrm{~s}$ & Ring torsion \\
\hline
\end{tabular}

$m, s$, and $b r$ stand for medium, strong, and broad, respectively. $v$ stands for stretching.

to contain $500 \mathrm{mg}$ of metronidazole per tablet. Sulperazone vials (Pfizer, Cairo, Egypt) were labeled to contain $1000 \mathrm{mg}$ of cefoperazone and $500 \mathrm{mg}$ of sulbactam per vial.

2.3. Disc Preparation and Recording of FTIR Spectra. Mixtures of drugs and $\operatorname{KBr}(1: 200)$ were grinded and mixed well in a glass mortar. The obtained mixtures were diluted to $1000 \mathrm{mg}$ with $\mathrm{KBr}$, then grinded again and pressed under $15000 \mathrm{lbs}$ by a hydraulic pressure system in the die press for $3 \mathrm{~min}$ to obtain sample discs. FTIR spectra were collected in the diffuse transmittance mode with potassium bromide as a diluent. The spectra were recorded in the range of $4000-$ $400 \mathrm{~cm}^{-1}$ at $4 \mathrm{~cm}^{-1}$ spectral resolution with the accumulation of 512 spectral scans. Triplicate spectra were averaged to obtain one spectrum for each sample.

2.4. Binary Mixtures of the Studied Drugs. CPM and MTZ were physically mixed with potassium bromide in various ratios. The calibration curves were constructed by plotting the average peak areas of the characteristic $v(\mathrm{C}=\mathrm{O})$ band at $1773 \mathrm{~cm}^{-1}$ for CPM and ring torsion band at $826 \mathrm{~cm}^{-1}$ for MTZ and the characteristic $v(\mathrm{C}=\mathrm{O})$ band at $1715 \mathrm{~cm}^{-1}$ for $\mathrm{CFZ}$ and ring torsion band at $1124 \mathrm{~cm}^{-1}$ for SBT as a function of the weight percentage $(\% \mathrm{w} / \mathrm{w})$ in the range of 5 95. 
TABLE 3: Quantitative parameters for the assay of the studied drugs by FTIR spectroscopy in pure forms.

\begin{tabular}{lcccc}
\hline Parameter $^{\mathrm{a}}(n)$ & CPM & MTZ & CFZ & SBT \\
\hline Linear range & $2.5-18$ & $1.04-10$ & $1.06-10$ & $1.5-12$ \\
Intercept $(a) \pm$ RMSD & $-0.1745 \pm 0.0578$ & $-0.2016 \pm 0.0150$ & $-0.1003 \pm 0.0302$ & $-0.0917 \pm 0.0102$ \\
Slope $(b) \pm$ RMSD & $0.2381 \pm 0.0047$ & $0.1439 \pm 0.0023$ & $0.2812 \pm 0.0046$ & $0.0740 \pm 0.0013$ \\
Correlation coefficient $(r)$ & 0.9994 & 0.9996 & 0.9996 & 0.9994 \\
Determination coefficient $\left(r^{2}\right)$ & 0.9988 & 0.9993 & 0.9992 & 0.9987 \\
Limit of detection $(\mathrm{LOD})^{\mathrm{b}}$ & $0.80(\mu \mathrm{g} / \mathrm{mg})$ & 0.35 & 0.35 & 0.46 \\
Limit of quantitation $(\mathrm{LOQ})^{\mathrm{b}}$ & $2.40(\mu \mathrm{g} / \mathrm{mg})$ & 1.04 & 1.06 & 1.37 \\
\hline
\end{tabular}

${ }^{a} n=$ three determinations.

${ }^{\mathrm{b}}$ The concentration by $\mu \mathrm{g} / \mathrm{mg}$.

TABLE 4: Assay of the studied drugs in binary mixtures by FTIR spectroscopy.

\begin{tabular}{lcccc}
\hline Parameter $^{\mathrm{a}}(n)$ & CPM & MTZ & CFZ & SBT \\
\hline Linear range & $5-95$ & $5-95$ & $5-95$ & $5-95$ \\
Intercept $(a) \pm$ RMSD & $-0.20175 \pm 0.07369$ & $-0.20280 \pm 0.01962$ & $0.15207 \pm 0.00305$ & $-0.04375 \pm 0.01673$ \\
Slope $(b) \pm$ RMSD & $11.958 \pm 0.29276$ & $7.1918 \pm 0.14795$ & $0.08987 \pm 0.00213$ & $2.6896 \pm 0.07249$ \\
Correlation coefficient $(r)$ & 0.9991 & 0.9994 & 0.9988 & 0.9982 \\
Determination coefficient $\left(r^{2}\right)$ & 0.9982 & 0.9987 & 0.9977 & 0.1 \\
Limit of detection (LOD) $^{\mathrm{b}}$ & 0.02 & 0.009 & 0.3 & 0.02 \\
Limit of quantitation $(\mathrm{LOQ})^{\mathrm{b}}$ & 0.06 & 0.03 & 0.06 & \\
\hline
\end{tabular}

${ }^{a} n=$ three determinations

${ }^{\mathrm{b}}$ The concentration by $\% \mathrm{w} / \mathrm{w}$.

TABLE 5: Recovery of standard drugs added to their dosage forms by the proposed FTIR method.

\begin{tabular}{lcccc}
\hline Drug & Dosage form & Declared amount $(\mathrm{mg})$ & Added amount $(\mathrm{mg})$ & $\begin{array}{c}\text { Recovery } \\
(\% \pm \mathrm{RMSD})^{\mathrm{a}}\end{array}$ \\
\hline CPM & Maxipime vials & 500 & 500 & $99.4 \pm 0.77$ \\
MTZ & Flagyl infusion & 500 & 500 & $98.8 \pm 0.80$ \\
CFZ & Peractam vials & 1000 & 1000 & $99.2 \pm 1.09$ \\
SBT & Peractam vials & 500 & 500 & $99.5 \pm 0.86$ \\
\hline
\end{tabular}

${ }^{\mathrm{a}}$ Values are the mean of three determinations.

The samples were analyzed in triplicates to determine the linearity of the constructed calibration curve.

\subsection{Apparatus}

2.5.1. FTIR Spectroscopy. FTIR spectra were collected in triplicates using a Nicolet 6700 FTIR Advanced Gold Spectrometer with OMNIC 8 software (Thermo Electron Scientific Instruments Corp., Madison, WI, USA) and Jasco 6000 FTIR (Hachioji, Tokyo, Japan).

All the FTIR spectra were exported to the Galactic SPC format and manipulated using GRAMS AI software (Galactic Industries, Salem, NH, USA, version 7.01)

2.5.2. Spectrophotometry. The absorbance of the studied drugs was measured using UV-1601 PC (Shimadzu, Kyoto, Japan) and Lambda-3 B (Perkin-Elmer Corporation, Norwalk, USA) ultraviolet-visible spectrophotometers with matched $1 \mathrm{~cm}$ quartz cells.

\section{Results and Discussion}

The FTIR spectra of CPM, MTZ, CFZ, and SBT were recorded in the range of $4000-400 \mathrm{~cm}^{-1}$ using the transmittance mode of operation. The FTIR spectra of these drugs are shown in Figures 2-7. These spectra have shown noticeable differences which are closely explored in the following subsections.

3.1. FTIR Spectroscopic Investigations of the Studied Drugs. The key FTIR spectral features of CPM are $v\left(\mathrm{NH}_{2}\right)$ band at $3234 \mathrm{~cm}^{-1}, v(\mathrm{NH})$ band at $3197 \mathrm{~cm}^{-1}, v(\mathrm{CH})_{\text {aromatic }}$ band at $3056 \mathrm{~cm}^{-1}, v(\mathrm{CH})_{\text {aliphatic }}$ band at $2938 \mathrm{~cm}^{-1}, v(\mathrm{C}=\mathrm{O})_{\text {lactam }}$ band at $1773 \mathrm{~cm}^{-1}, v(\mathrm{C}=\mathrm{O})_{\text {carboxylic }}$ band at $1680 \mathrm{~cm}^{-1}$, and $v(\mathrm{C}=\mathrm{O})_{\text {amide }}$ band at $1657 \mathrm{~cm}^{-1}$. MTZ, in turn, is characterized by $v(\mathrm{OH})_{\text {alcoholic }}$ band at $3230 \mathrm{~cm}^{-1}, v(\mathrm{CH})_{\text {aromatic }}$ band at $3097 \mathrm{~cm}^{-1}, v(\mathrm{CH})_{\text {aliphatic }}$ band at $2950 \mathrm{~cm}^{-1}$, and $v\left(\mathrm{NO}_{2}\right)$ band at $1535 \mathrm{~cm}^{-1}$ and the ring torsion band at $826 \mathrm{~cm}^{-1}$. The distinctive FTIR wave numbers of the combinations of CPM and CFZ are listed in Table 1. 
TABLE 6: The precision of the proposed FTIR method.

\begin{tabular}{|c|c|c|c|c|c|c|c|c|c|}
\hline \multirow[t]{2}{*}{ Drug } & \multirow[t]{2}{*}{ Concentration $(\mu \mathrm{g} / \mathrm{mg})$} & \multicolumn{5}{|c|}{$\begin{array}{c}\text { Absorbance } \\
\text { Sample number }\end{array}$} & \multirow{2}{*}{ Mean } & \multirow[t]{2}{*}{$\mathrm{RMSD}^{\mathrm{a}}$} & \multirow[t]{2}{*}{$\mathrm{CV}(\mathrm{RMSD})^{\mathrm{b}}(\%)$} \\
\hline & & 1 & 2 & 3 & 4 & 5 & & & \\
\hline$\overline{\mathrm{CPM}}$ & 8 & 0.345 & 0.346 & 0.340 & 0.335 & 0.332 & 0.340 & 0.0061 & 1.79 \\
\hline MTZ & 5 & 0.646 & 0.649 & 0.655 & 0.640 & 0.634 & 0.645 & 0.0081 & 1.26 \\
\hline CFZ & 5 & 0.579 & 0.570 & 0.583 & 0.567 & 0.586 & 0.577 & 0.0082 & 1.42 \\
\hline SBT & 8 & 0.365 & 0.373 & 0.360 & 0.354 & 0.357 & 0.362 & 0.0074 & 2.06 \\
\hline
\end{tabular}

${ }^{\mathrm{a}} \mathrm{RMSD}$ : root mean square deviation.

${ }^{\mathrm{b}} \mathrm{CV}$ (RMSD): coefficient of variation (root mean square deviation).

TABLE 7: The ruggedness of the proposed FTIR method.

\begin{tabular}{lcccc}
\hline & \multicolumn{4}{c}{ Recovery $(\% \pm \text { RMSD })^{\text {a }}$} \\
Drug & Instrument & \multicolumn{2}{c}{ Interday variation } \\
& Nicolet 6700 & Jasco 6000 & 1 day & 2 days \\
\hline CPM & $99.4 \pm 0.77$ & $99.5 \pm 0.83$ & $99.4 \pm 0.77$ & $99.7 \pm 0.67$ \\
MTZ & $98.8 \pm 0.80$ & $99.2 \pm 0.66$ & $98.8 \pm 0.80$ & $99.1 \pm 0.80$ \\
CFZ & $99.2 \pm 1.09$ & $99.6 \pm 1.05$ & $99.2 \pm 1.05$ & $99.5 \pm 1.15$ \\
SBT & $99.3 \pm 0.95$ & $99.6 \pm 1.05$ & $99.3 \pm 0.96$ & $99.6 \pm 0.85$ \\
\hline
\end{tabular}

${ }^{a}$ Values are the mean of three determinations \pm RMSD

The key FTIR spectral features of CFZ are $v(\mathrm{OH})_{\text {phenolic }}$ band at $3423 \mathrm{~cm}^{-1}, v(\mathrm{NH})$ band at $3297 \mathrm{~cm}^{-1}, v(\mathrm{CH})$ aromatic band at $3090 \mathrm{~cm}^{-1}, v(\mathrm{CH})_{\text {aliphatic }}$ band at $2950 \mathrm{~cm}^{-1}$, $v(\mathrm{C}=\mathrm{O})_{\text {lactam }}$ band at $1773 \mathrm{~cm}^{-1}, v(\mathrm{C}=\mathrm{O})_{\text {carboxylic }}$ band at $1717 \mathrm{~cm}^{-1}$, and $v(\mathrm{C}=\mathrm{O})_{\text {amide }}$ band at $1669 \mathrm{~cm}^{-1}$. SBT, in turn, is characterized by $v(\mathrm{CH})_{\text {aromatic }}$ band at $3082 \mathrm{~cm}^{-1}$, $v(\mathrm{CH})_{\text {aliphatic }}$ band at $2964 \mathrm{~cm}^{-1}, v(\mathrm{C}=\mathrm{O})_{\text {lactam }}$ band at $1767 \mathrm{~cm}^{-1}$, and $v(\mathrm{O}=\mathrm{S}=\mathrm{O})$ band at $1030 \mathrm{~cm}^{-1}$ and the ring torsion band at $1124 \mathrm{~cm}^{-1}$. The distinctive FTIR wave numbers of the combinations of CFZ and SBT are listed in Table 2.

3.2. Quantitative Determination and Validation. The FTIR spectroscopy has been utilized for the quantitative determination of the studied combinations. The $v(\mathrm{C}=\mathrm{O})$ band at $1773 \mathrm{~cm}^{-1}$ for CPM and ring torsion band at $826 \mathrm{~cm}^{-1}$ for MTZ (Figures 4 and 5) and the $v(\mathrm{C}=\mathrm{O})$ band at $1715 \mathrm{~cm}^{-1}$ for $\mathrm{CFZ}$ and ring torsion band at $1124 \mathrm{~cm}^{-1}$ for SBT (Figures 6 and 7) were picked up for their quantitative determination because they are well resolved and free from interferences. The peak areas of the bands of interest were integrated using GRAMS AI package. The developed procedures were validated according to USP 2009 validation guidelines [1] and the International Conference on Harmonization (ICH) guidelines [2].

3.2.1. Linearity and Range. Under the optimal reaction conditions, a series of concentrations of the cited drugs was processed into sample discs and the FTIR spectra were recorded. Calibration curves were constructed by plotting peak areas of the selected FTIR absorption bands as a function of the corresponding concentrations in $\% \mathrm{w} / \mathrm{w}$. The obtained linear concentration ranges were $1.0-18$ and $1.0-12 \mu \mathrm{g} / \mathrm{mg}$ for CPM-MTZ and CFZ-SBT, respectively.
TABLE 8: The analysis of investigated drugs in their dosage form using the proposed FTIR and reported methods.

\begin{tabular}{lcccc}
\hline Product & $\begin{array}{c}\text { Recovery }(\% \pm \text { RMSD })^{\mathrm{a}} \\
\text { Proposed } \\
\text { method }\end{array}$ & $\begin{array}{c}\text { Reported } \\
\text { methods [3, 4] }\end{array}$ & F-value & \\
\hline Maxipime vial & $99.60 \pm 0.29$ & $99.82 \pm 0.34$ & 3.04 & 1.47 \\
Flagyl tablet & $98.90 \pm 1.24$ & $99.69 \pm 1.86$ & 2.42 & 1.02 \\
Peractam vial & $99.40 \pm 0.35$ & $99.5 \pm 0.8$ & 2.57 & 1.40 \\
\hline
\end{tabular}

${ }^{\mathrm{a}}$ Values are the mean of three determinations \pm RMSD.

${ }^{\mathrm{b}}$ Theoretical values for $t$ and $F$ at $95 \%$ confidence limit $(n=5)$ were 2.78 and 6.39 , respectively.

The correlation coefficients were in the range from 0.9994 to 0.9996 for the studied drugs in pure forms and from 0.9982 to 0.9987 and from 0.9964 to 0.9977 for CPM-MTZ and CFZ-SBT binary mixtures, respectively.

3.2.2. Limits of Detection and Quantitation. The LOD and LOQ values were determined from the linear calibration range for the studied drugs either alone or in combinations. The calculated LODs and LOQs were in the range of $0.35-0.80 \mu \mathrm{g} / \mathrm{mg}$ and $1.04-2.40 \mu \mathrm{g} / \mathrm{mg}$ for the studied drugs in their pure forms while, in their binary mixtures, they were in the range of $0.009-0.1 \% \mathrm{w} / \mathrm{w}$ and $0.03-0.3 \% \mathrm{w} / \mathrm{w}$, respectively. The results are presented in Tables 3 and 4 .

3.2.3. Accuracy and Precision. The accuracy of the proposed method was assessed by the standard addition method. The recovery values of the added concentrations were $99.4 \pm 0.77,98.8 \pm 0.80,99.2 \pm 1.09$, and $99.5 \pm 0.86$ for CPM, MTZ, CFZ, and SBT, respectively, in their pure forms (Table 5) which would indicate the accuracy of the proposed method.

The precision of the method was determined by conducting replicate analysis of five samples of each investigated drug. The coefficient of variation of root mean square deviation (CV (RMSD)) was lower than 2.5\%. Accordingly, the proposed method is sufficiently reproducible (Table 6).

3.2.4. Ruggedness. Ruggedness was also evaluated by applying the proposed method to the assay of the investigated drugs using the same procedure but using two different instruments of two different laboratories with different elapsed times. The results were found to be reproducible (Table 7). 
3.3. Application of the Analysis of the Pharmaceutical Dosage Forms. The proposed method was applied to the determination of CPM, MTZ, CFZ, and SBT in their commercial dosage forms in the Egyptian market. The results are presented in Table 8 . The mean recovery percentages were found to be $99.60 \pm 0.29 \%, 98.90 \pm 1.24 \%$, and $99.40 \pm 0.35 \%$ for cefepime (Maxipime vial), metronidazole (Flagyl tablets), and cefoperazone-sulbactam (Peractam vial), respectively. The results were compared with those obtained by the reported methods $[3,4]$ (Table 8 ) at $95 \%$ confidence level. No significant difference was found between the calculated and theoretical values of the $t$ and $f$ tests which indicate good level of precision and accuracy of the proposed method.

\section{Conclusions}

The key FTIR spectral features of each of the investigated drugs were reliably determined. The FTIR spectroscopy has been utilized for the first time to quantify the studied drugs and their binary mixtures in the solid state. The results were reliably compared with other relevant and previously published spectrophotometric methods. This vibrational spectroscopic technique appears to be a good alternative to other well-established analytical techniques especially in the absence of suitable methods for the determination of the active ingredients that are present in complex matrices as in the pharmaceutical formulations.

\section{Conflicts of Interest}

The authors declare that they have no conflicts of interest.

\section{References}

[1] United State Pharmacopoeia 36 and National Formulary 29, Convention, Rockville, MD, 2012.

[2] S. K. Branch, "Guidelines from the International Conference on Harmonisation (ICH)," Journal of Pharmaceutical and Biomedical Analysis, vol. 38, no. 5, pp. 798-805, 2005.

[3] R. K. Nanda, D. A. Navathar, A. A. Kulkarni, and S. S. Patil, "Simultaneous spectrophotometric estimation of cefepime and tazobactam in pharmaceutical dosage form," International Journal of Chemical Technology Research, vol. 4, pp. 152-156, 2012.

[4] M. R. El-Ghobashy and N. F. Abo-Talib, "Spectrophotometric methods for the simultaneous determination of binary mixture of metronidazole and diloxanide furoate without prior separation," Journal of Advanced Research, vol. 1, no. 4, pp. 323-329, 2010.

[5] F. C. Maddox and J. T. Stewart, "HPLC determination of an aqueous cefepime and metronidazole mixture," Journal of liquid chromatography \& related technologies, vol. 22, no. 18, pp. 2807-2813, 1999.

[6] Pharmacopoeia B., "British Pharmacopoeia Commission London; the Department of Health," Social Services and Public Safety, vol. 1, pp. 719-720, 2013.

[7] V. D. Hoang, N. Thi Tho, V. Thi Tho, and M. T. Nguyen, "UV spectrophotometric simultaneous determination of cefoperazone and sulbactam in pharmaceutical formulations by derivative, Fourier and wavelet transforms," Spectrochim Acta Part A, vol. 121C, pp. 704-714, 2014.

[8] Chapter, G., 1225, "Validation of compendial methods," in United States Pharmacopeia 30, National Formulary 25, The United States Pharmacopeial Convention, Rockville, Md., USA, 2007.

[9] M. K. Ahmed, J. K. Daun, and R. Przybylski, "FT-IR based methodology for quantitation of total tocopherols, tocotrienols and plastochromanol-8 in vegetable oils," Journal of Food Composition and Analysis, vol. 18, no. 5, pp. 359-364, 2005.

[10] N. Al-Zoubi, J. E. Koundourellis, and S. Malamataris, "FT-IR and Raman spectroscopic methods for identification and quantitation of orthorhombic and monoclinic paracetamol in powder mixes," Journal of Pharmaceutical and Biomedical Analysis, vol. 29, no. 3, pp. 459-467, 2002.

[11] D. E. Bugay, A. W. Newman, and W. P. Findlay, "Quantitation of cefepime $2 \mathrm{HCl}$ dihydrate in cefepime $2 \mathrm{HCl}$ monohydrate by diffuse reflectance IR and powder X-ray diffraction techniques," Journal of Pharmaceutical and Biomedical Analysis, vol. 15, no. 1, pp. 49-61, 1996.

[12] S. Matkovic, G. M. Valle, and L. E. Briand, "Quantitative analysis of ibuprofen in pharmaceutical formulations through FTIR spectroscopy," Latin American Applied Research, vol. 35, no. 3, pp. 189-195, 2005.

[13] A. Peepliwal, S. D. Vyawahare, and C. G. Bonde, "A quantitative analysis of Zidovudine containing formulation by FT-IR and UV spectroscopy," Analytical Methods, vol. 2, no. 11, pp. 1756-1763, 2010.

[14] F. B. Reig, J. G. Adelantado, V. P. MartnezMartínez, M. M. Moreno, and M. D. Carbó, "FT-IR quantitative analysis of solvent mixtures by the constant ratio method," Journal of molecular structure, vol. 480, pp. 529-534, 1999.

[15] Y. Roggo, P. Chalus, L. Maurer, C. Lema-Martinez, A. Edmond, and N. Jent, "A review of near infrared spectroscopy and chemometrics in pharmaceutical technologies," Journal of pharmaceutical and biomedical analysis, vol. 44, no. 3, pp. 683-700, 2007.

[16] H. R. Ali, G. A. Saleh, S. A. Hussein, and A. I. Hassan, "In-depth qualitative and quantitative FTIR spectroscopic study of glipizide and gliclazide," Analytical Chemistry: An Indian Journal, vol. 14, no. 4, pp. 127-134, 2014. 

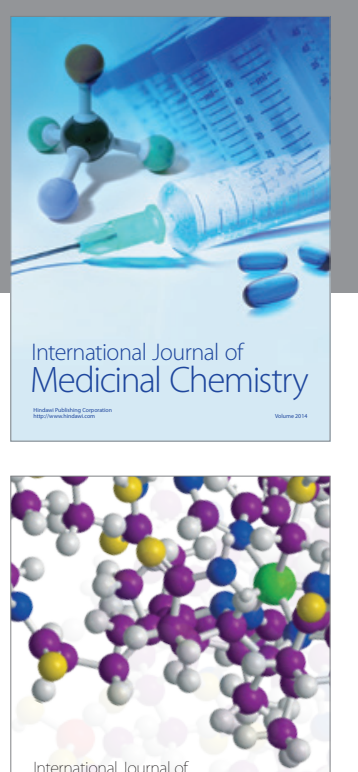

Carbohydrate Chemistry

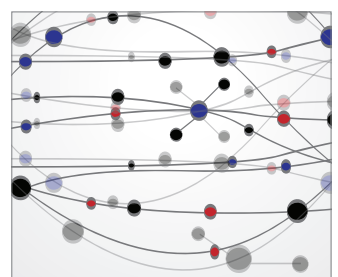

The Scientific World Journal
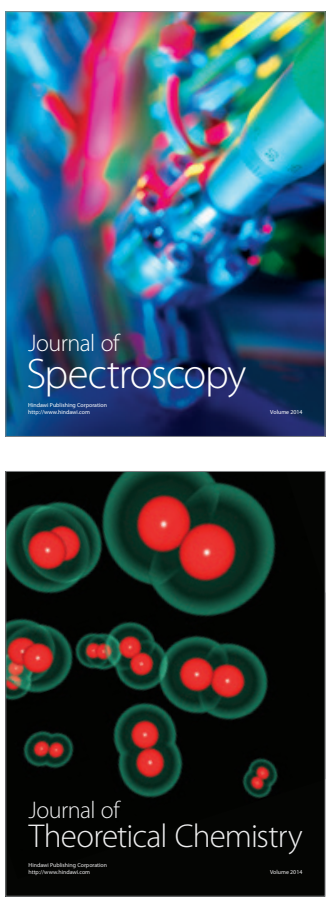
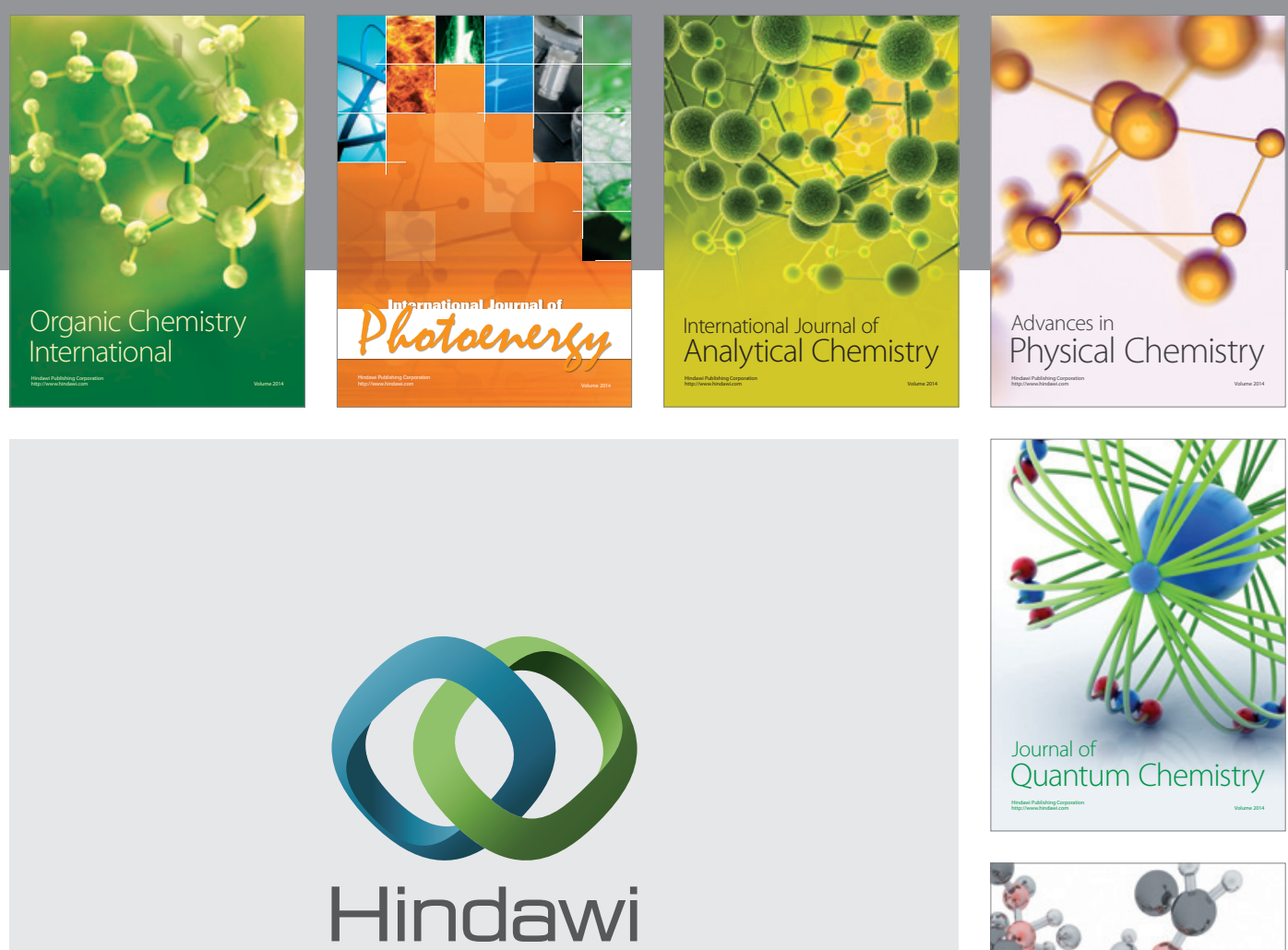

Submit your manuscripts at

https://www.hindawi.com

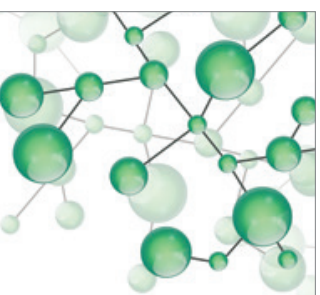

International Journal of

Inorganic Chemistry
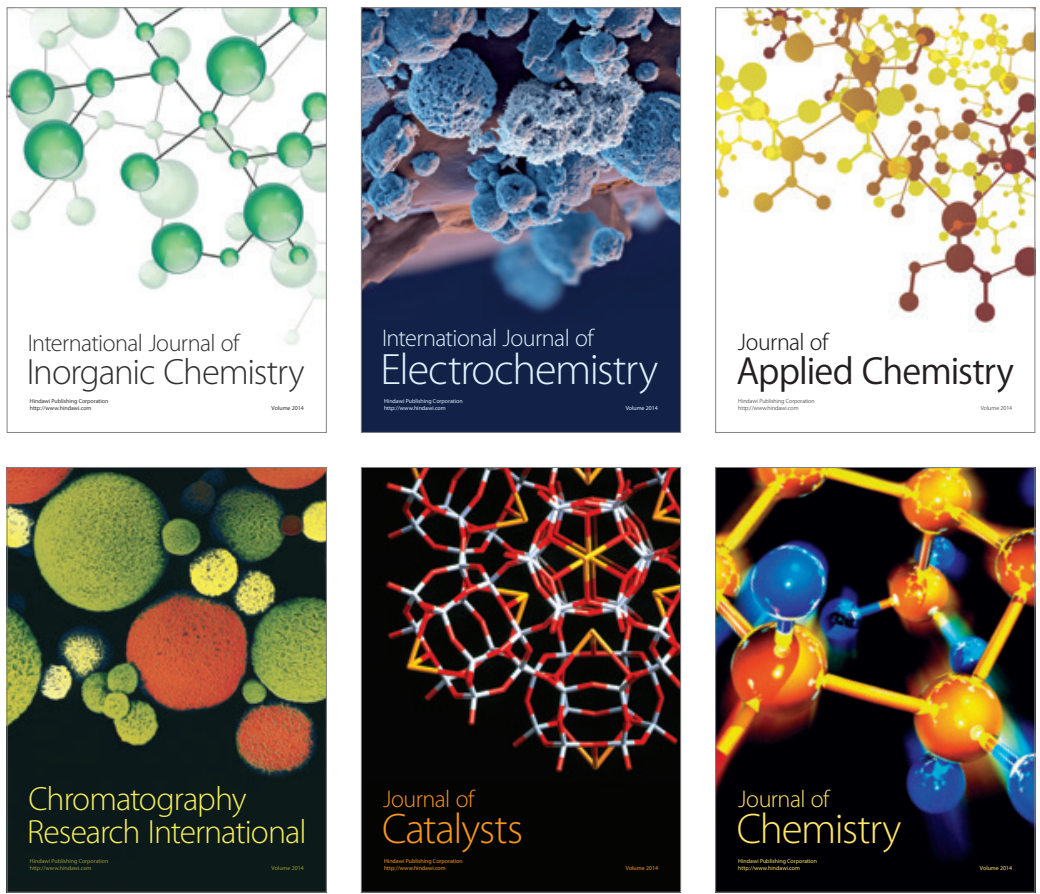

Journal of

Applied Chemistry
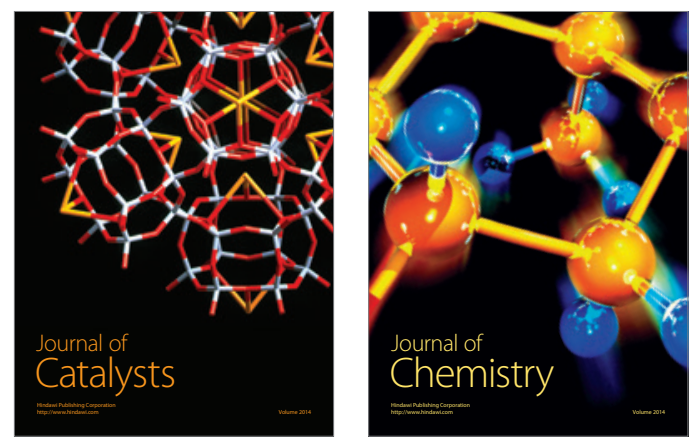
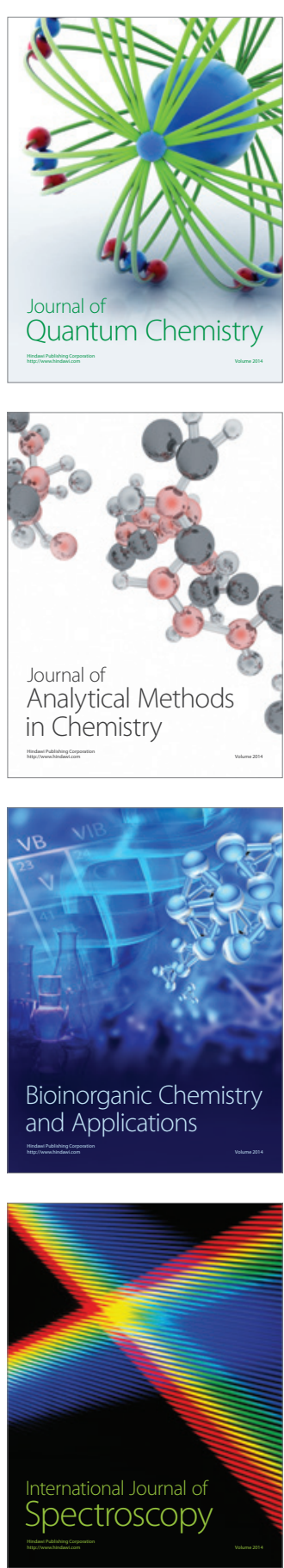